\title{
PENGARUH STRUKTUR MODAL DAN STRUKTUR KEPEMILIKAN TERHADAP KINERJA PERUSAHAAN DENGAN CORPORATE GOVERNANCE SEBAGAI VARIABEL MODERASI
}

\author{
Maretha Kris Dwi Anggreni \\ Universitas Kristen Satya Wacana, Indonesia \\ Robiyanto* \\ Universitas Kristen Satya Wacana, Indonesia
}

\begin{abstract}
This study aims to examine the effect of capital structure and ownership on company performance with moderation of corporate governance in trade, service and investment sector companies in 20162019. The research data was obtained from the Indonesian Capital Market Directory (ICMD) and the annual financial reports listed on the Indonesia Stock Exchange. The total sample obtained based on the purposive sampling method was 76 samples and tested using the Eviews 9 analysis tool. The analysis technique used panel data regression analysis and Moderated Regression Analysis (MRA). Capital structure and corporate governance as proxied by the role of independent commissioners are proven to improve company performance. The implication of this research is to provide empirical evidence regarding the role of corporate governance in moderating capital structure and ownership structure on company performance. The use of debt in the capital structure can have a positive influence on the company's performance. So the applied implication for the company is that it can increase debt in its capital structure by taking into account the optimal point. In addition, companies can optimize the role of independent commissioners as corporate governance to improve supervision within the company so as to improve company performance.
\end{abstract}

JEL : G30, G32, G34

Keywords : capital structure, ownership structure, foreign ownership, family ownership, corporate governance, company performance.

\begin{abstract}
ABSTRAK
Penelitian ini bertujuan menguji pengaruh struktur modal dan kepemilikan terhadap kinerja perusahaan dengan moderasi corporate governance pada perusahaan sektor perdagangan, jasa dan investasi tahun 2016-2019. Data penelitian ini diperoleh dari Indonesian Capital Market Directory (ICMD) dan laporan keuangan tahunan yang tercatat pada Bursa Efek Indonesia. Total sampel diperoleh berdasarkan metode pengumpulan data purposive sampling adalah sebanyak 76 sampel dan diuji menggunakan alat analisis Eviews 9. Teknik analisis pada penelitian ini menggunakan analisis regresi data panel dan Moderated Regression Analysis (MRA). Variabel struktur modal serta variabel moderasi corporate governance yang diproksikan dengan peran komisaris independen terbukti dapat meningkatkan kinerja perusahaan. Implikasi dari penelitian ini adalah memberikan bukti secara empiris terkait peran corporate governance dalam memoderasi struktur modal dan struktur kepemilikan terhadap kinerja perusahaan. Penggunaan utang pada struktur modal mampu memberikan pengaruh positif terhadap kinerja perusahaan. Maka implikasi terapan bagi perusahaan yaitu dapat meningkatkan utang pada struktur modalnya dengan memperhatikan titik optimal. Selain itu, perusahaan dapat mengoptimalkan peran komisaris independen sebagai corporate governance untuk meningkatkan pengawasan dalam perusahaan sehingga meningkatkan kinerja perusahaan.
\end{abstract}

Kata Kunci : struktur modal, struktur kepemilikan, kepemilikan asing, kepemilikan keluarga, corporate governance, kinerja perusahaan.

\section{PENDAHULUAN}

Struktur modal dalam perusahaan dapat menjadi salah satu cara untuk dapat meningkatkan nilai shareholders (Kayo \& Kimura, 2011). Struktur modal dapat digunakan sebagai pendanaan

\footnotetext{
*Email : robiyanto.robiyanto@uksw.edu

Received : 20-02-2021, Accepted : 20-08-2021, Published : 29-08-2021

P-ISSN : 2087-9954, E-ISSN : 2550-0066. DOI : http://dx.doi.org/10.26418/jebik.v10i2.45162
} 
dalam perusahaan, maka penting untuk memperhatikan pengelolaan serta pengawasannya. Pengaruh positif ditemukan pada hubungan struktur modal terhadap kinerja perusahaan, tetapi keduanya akan berpengaruh negatif pada titik tertentu yaitu saat jumlah utang dalam perusahaan meningkat (Haryono, Fitriany, \& Fatima, 2017). Utang akan menimbulkan efek negatif pada nilai perusahaan sebagai akibat dari kurangnya investasi (Margaritis \& Psillaki, 2010). Model ini ditunjukkan pada penelitian Myers (1977); Jensen \& Meckling (1976); Stulz (1990) yaitu pembiayaan utang dapat mengurangi masalah kelebihan investasi, tetapi berdampak pula pada masalah kekurangan investasi. Margaritis \& Psillaki (2010) menyebutkan bahwa kepemilikan yang lebih terkonsentrasi sering dikaitkan dengan utang yang tinggi dalam struktur modal.

Pada pasar maju dan pasar berkembang ditemukan konsentrasi kepemilikan yang tinggi dan menimbulkan masalah keagenan pada shareholders mayoritas dan minoritas (Morck, Wolfenzon, \& Yeung, 2005). Konflik kepentingan juga dapat terjadi pada manajer dan shareholders. Manajer sebagai pihak yang ikut serta secara langsung dalam berlangsungnya kegiatan perusahaan akan memiliki akses informasi yang lebih dibandingkan shareholders. Kondisi tersebut berpotensi pada timbulnya masalah keagenan antara manajer dengan shareholders, karena itu praktik tata kelola perusahaan mencoba menyelaraskan kepentingan antara kedua pihak tersebut (Abdallah \& Ismail, 2017).

Kepemilikan saham oleh keluarga dalam perusahaan dapat mengurangi dampak negatif dari masalah keagenan. Purkayastha, Veliyath, \& George, (2019) menemukan bahwa perusahaan yang kepemilikan dan pengelolaannya dilakukan oleh keluarga, tidak menunjukkan adanya efek negatif dari konflik shareholders dengan manajer terhadap nilai pemegang saham. Penelitian sebelumnya terkait kepemilikan keluarga oleh Astuti, Rahman, \& Sudarno (2015) juga menemukan bahwa kinerja perusahaan dapat dipengaruhi secara positif oleh kepemilikan keluarga. Berbeda dengan penelitian dari Widyawati, Trinugroho, \& Untoro (2018); Roossiana \& Bustaman (2015); Wiranata \& Nugrahanti (2013), dimana kepemilikan keluarga memiliki pengaruh negatif pada perusahaan. Kepemilikan keluarga dalam penelitian tersebut secara negatif berpengaruh terhadap strategi pengambilan risiko perusahaan dan profitabilitas perusahaan.

Selain kepemilikan keluarga, dalam kajian literatur lain juga ditemukan bahwa kepemilikan asing dapat memberikan keunggulan kinerja bagi perusahaan. Penelitian tentang kepemilikan asing pada bank komersial di Indonesia menunjukkan pengaruh yang positif terhadap efisiensi industri perbankan di Indonesia, dimana kepemilikan asing lebih efisien apabila dibandingkan dengan kepemilikan domestik (Ghofar \& Noviandry, 2018). Hasil penelitian oleh Carney, Estrin, Liang, \& Shapiro (2019) menunjukkan kepemilikan asing dalam perusahaan memiliki keunggulan kinerja dibandingkan perusahaan domestik. Hasil tersebut sesuai dengan penelitian lain terkait kepemilikan asing yang ditemukan Wiranata \& Nugrahanti (2013) yaitu profitabilitas perusahaan dapat dipengaruhi secara positif oleh kepemilikan asing.

Penelitian terkait struktur modal dan struktur kepemilikan terhadap kinerja perusahaan telah dilakukan oleh Haryono et al. (2017), meneliti pada perusahaan non keuangan yang tercatat di Bursa Efek Indonesia. Mekanisme tata kelola perusahaan pada penelitian tersebut masih terbatas dari peranan multiple large shareholders structure dan kepemilikan institusional. Penelitian ini akan mereplikasi penelitian Haryono et al. (2017) dengan menambahkan peranan corporate governance sebagai variabel moderasi serta menambahkan struktur kepemilikan lain yaitu kepemilikan asing dan kepemilikan keluarga sebagai variabel independen. Hal ini karena di 
Indonesia ditemukan adanya struktur kepemilikan yang terkonsentrasi dan berdampak pada munculnya masalah keagenan (Wiranata \& Nugrahanti, 2013).

Perusahaan dengan corporate governance yang baik akan lebih disukai oleh investor maupun kreditur, karena corporate governance memiliki fungsi pengawasan dalam perusahaan, sehingga kepentingan antara pengelola dan pemilik perusahaan akan sama-sama tercapai. Tercapainya kepentingan antara pemilik dan pengelola perusahaan akan mengurangi biaya agensi sehingga hal tersebut berpengaruh pada peningkatan kinerja perusahaan (Moradi \& Velashani, 2017). Corporate governance dapat menjadi salah satu alternatif dalam meyakinkan investor karena dengan adanya penerapan corporate governance diharapkan dapat tercipta tata kelola perusahaan yang dapat melindungi hak pemangku kepentingan terutama kepemilikan asing dan kepemilikan keluarga. Selain itu, corporate governance dapat berperan membantu fungsi pengawasan dari utang sehingga tercipta pengawasan perusahaan yang semakin efektif dan dapat meningkatkan kinerja perusahaan.

Penelitian ini akan meneliti perusahaan-perusahaan sektor perdagangan, jasa, dan investasi periode 2016-2019 yang tercatat di Bursa Efek Indonesia (BEI). Sektor ini dipilih karena adanya kepemilikan yang terkonsentrasi pada perusahaan sampel yang ditunjukkan pada laporan tahunan perusahaan sektor perdagangan, jasa, dan investasi tahun 2016-2019. Kepemilikan yang terkonsentrasi ditunjukkan dengan adanya kepemilikan saham perusahaan $>5 \%$ (Nguyen et al., 2014). Selain itu, kapitalisasi pasar, Price to Book Value (PBV), dan Debt to Equity Ratio (DER) pada tahun 2017 pada sektor perdagangan, jasa, dan investasi menunjukkan peningkatan, terutama peningkatan pada nilai PBV yang meningkat cukup tinggi dari 1,94x menjadi 6,43x. Namun nilai kapitalisasi pasar, PBV, dan DER tersebut pada tahun 2018 dan tahun 2019 mengalami penurunan.

Tabel 1. Statistik Sektor Perdagangan, Jasa, dan Investasi

\begin{tabular}{ccccc}
\hline Tahun & $\begin{array}{c}\text { Jumlah } \\
\text { Perusahaan }\end{array}$ & Kapitalisasi Pasar & $\begin{array}{c}\text { PBV } \\
(\mathbf{x})\end{array}$ & $\begin{array}{c}\text { DER } \\
(\mathbf{x})\end{array}$ \\
\hline 2016 & 120 & 627.975 .000 .000 .000 & 1,94 & 1,20 \\
2017 & 133 & 745.845 .000 .000 .000 & 6,43 & 1,29 \\
2018 & 153 & 680.229 .000 .000 .000 & 2,72 & 1,03 \\
2019 & 168 & 687.480 .000 .000 .000 & 2,56 & 0,40 \\
\hline \multicolumn{4}{l}{ Sumber: Bursa Efek Indonesia (2020) }
\end{tabular}

Sumber: Bursa Efek Indonesia (2020)

Pokok permasalahan pada penelitian ini adalah "Bagaimana struktur modal dan struktur kepemilikan berpengaruh terhadap kinerja perusahaan" serta "Bagaimana tata kelola perusahaan dapat memoderasi pengaruh struktur modal dan struktur kepemilikan terhadap kinerja perusahaan". Penelitian ini akan menguji pengaruh dua variabel yaitu struktur modal dan kepemilikan yang diuji pengaruhnya terhadap kinerja perusahaan pada sektor perdagangan, jasa, dan investasi periode 2016-2019, dan apabila dimoderasi oleh variabel tata kelola perusahaan. Penelitian ini memberikan manfaat yaitu membuktikan secara empiris bagaimana kinerja perusahaan dipengaruhi oleh struktur modal dan struktur kepemilikan apabila dimoderasi dengan tata kelola perusahaan, serta memberikan gambaran kepada calon investor mengenai struktur modal dan struktur kepemilikan perusahaan pada sektor perdagangan, jasa, dan investasi pada periode 2016-2019.

\section{KAJIAN LITERATUR}

Struktur modal adalah usaha manajemen memenuhi kebutuhan aktivitas perusahaan melalui pendanaan. Tujuan dari struktur modal adalah dapat menciptakan perbandingan utang dan 
modal usaha yang dapat memberikan keuntungan serta meningkatkan kinerja perusahaan (Noviani, Atahau, \& Robiyanto, 2019). Teori trade-off dari Myers (1977), menjelaskan bahwa utang pada batas tertentu dapat berperan untuk meningkatkan kinerja perusahaan.

Struktur kepemilikan adalah komposisi kepemilikan saham pada perusahaan yang kepemilikannya dapat berupa kepemilikan individu, institusi maupun publik yang digunakan untuk mengurangi adanya masalah keagenan. Masalah keagenan dijelaskan pada penelitian Jensen \& Meckling (1976) yaitu agent dan principal sering mempunyai tujuan yang tidak selaras yang menimbulkan adanya masalah keagenan yang kemudian disebut dengan teori keagenan. Struktur kepemilikan dalam perusahaan dapat berupa kepemilikan asing dan kepemilikan keluarga. Kepemilikan asing adalah saham biasa yang tidak berasal dari Indonesia dan kepemilikannya dapat dimiliki oleh perorangan dan badan hukum. Selain itu pemerintah dan bagiannya yang berstatus luar negeri dapat menjadi pihak yang berstatus sebagai kepemilikan asing (Wiranata \& Nugrahanti, 2013). Zraiq \& Fadzil (2018) mendefinisikan kepemilikan asing sebagai jenis kepemilikan dengan persentase investor asing tertentu yang berinvestasi dalam perusahaan di pasar domestik. Sedangkan, kepemilikan keluarga mengacu pada definisi bahwa keluarga dalam perusahaan menggunakan kekuasaan dan arahan strateginya melalui kepemilikan, manajemen puncak, atau posisi dewan pengurus (Pieper, Klein, \& Jaskiewicz, 2008). Kehadiran anggota keluarga dalam perusahaan akan mengurangi pengaruh negatif dari masalah agensi yang ditimbulkan oleh direktur non keluarga (Astuti et al., 2015).

Penelitian yang dilakukan oleh Febrianti \& Dewi (2019) menyebutkan bahwa untuk meningkatkan nilai dan mencapai tata kelola perusahaan yang baik perusahaan membutuhkan pihak atau kelompok yang dapat mengawasi perusahaan. Tata kelola perusahaan (corporate governance) sebagai mekanisme pengawasan dalam perusahaan bertujuan melindungi hak pemangku kepentingan (Noviani et al., 2019). Tata kelola perusahaan di Indonesia menganut tata kelola dua tingkat, yaitu memisahkan fungsi dari dewan komisaris dan direksi (Ditta \& Setiawan, 2019). Hal ini terdapat dalam UU Nomor 40 Tahun 2007 pasal 1 yang mengatur dewan komisaris dan direksi terkait tugas dan wewenangnya dalam perusahaan. Dewan komisaris bertugas dalam hal pengawasan serta memberikan nasihat kepada direksi. Sedangkan direksi adalah pihak yang memiliki wewenang dan yang akan bertanggung jawab atas pengelolaan perseroan.

Pengawasan oleh komisaris independen akan semakin efektif ketika proporsi komisaris independen besar (Agustin \& Oktavianna, 2019). Kepemilikan institusional sebagai salah satu variabel pengukuran moderasi corporate governance juga memberikan fungsi pengawasan yaitu dari mutual funds dan dana pensiun (Surjadi, Vania, Wijantini, \& Yuliati, 2018). Surjadi et al. (2018) juga menjelaskan bahwa kepemilikan institusional akan menekan konflik agensi serta mencegah tindakan manipulatif karena pihak institusi melakukan kontrol langsung kinerja perusahaan. Selain komisaris independen dan kepemilikan institusional, pengukuran corporate governance juga dapat menggunakan variabel kepemilikan manajerial. Manajer akan bertindak sebagai pengelola serta pemilik perusahaan sehingga diharapkan masalah keagenan dapat diminimalisir dengan adanya pengungkapan informasi yang lebih baik (Wendy, 2020).

\subsection{Pengaruh Struktur Modal terhadap Kinerja Perusahaan}

Kinerja perusahaan dapat dipengaruhi secara positif oleh struktur modal, hal ini dijelaskan pada penelitian Haryono et al. (2017) dimana manfaat pajak membuat adanya pengaruh positif struktur modal terhadap kinerja perusahaan. Semakin besar manfaat penghematan pajak maka 
pengaruhnya pada nilai perusahaan juga semakin besar yang diakibatkan dari penggunaan utang dimana utang tersebut mempengaruhi beban bunga (Uzliawati, Nofianti, \& Ratnasari, 2016). Uzliawati et al. (2016) membuktikan bahwa struktur modal tidak hanya sebagai sumber modal eksternal namun juga dapat bermanfaat sebagai perlindungan pajak dan dapat memberikan sinyal positif untuk meningkatkan nilai perusahaan. Perlindungan pajak yang dimaksud adalah pada bunga utang, yang dalam perhitungan pajak harus dikurangkan terlebih dahulu. Oluwagbemiga (2013) pada penelitiannya menemukan bahwa sebagian besar perusahaan di Kenya menggunakan lebih banyak utang untuk sumber pembiayaan daripada modal ekuitas dari pemegang saham. Hal ini disebabkan pembiayaan melalui modal ekuitas akan memerlukan kepemilikan perusahaan, dimana perusahaan akan memberikan hak tertentu kepada orang lain.

Penelitian terkait penggunaan utang di Indonesia khususnya pada perusahaan manufaktur yang dilakukan oleh Wijaya \& Wardani (2017), menemukan bahwa penggunaan utang pada perusahaan tersebut masih tinggi, dimana pada perusahaan tersebut terdapat kepemilikan saham yang besar oleh pemegang saham mayoritas dan manajer puncak. Ketika utang meningkat, utang dapat menjadi salah satu mekanisme disiplin untuk mengurangi konflik keagenan antara kepemilikan mayoritas dan minoritas (Hassan, 2016). Selain itu, utang dalam perusahaan dapat berperan dalam pengendalian penggunaan dana kas secara bebas dan berlebihan Hermuningsih (2013), sehingga dengan adanya utang ini perusahaan dapat meningkatkan kontrol pada penggunaan dana kas dan meningkatkan kinerja perusahaan. Berdasarkan uraian tersebut struktur modal dipersepsikan akan meningkatkan kinerja perusahaan, sehingga dapat dirumuskan bahwa struktur modal mempengaruhi kinerja perusahaan secara positif.

\subsection{Pengaruh Kepemilikan Asing terhadap Kinerja Perusahaan}

Kepemilikan asing dalam perusahaan dianggap mampu meningkatkan kinerja perusahaan, yaitu melalui investasi yang memiliki sistem dan teknologi yang selalu ditingkatkan (Ditta \& Setiawan, 2019). Kepemilikan asing berdampak efektif pada fungsi pemantauan manajemen perusahaan (Musallam, 2015). Kepemilikan asing diharapkan dapat mengurangi konflik agensi yaitu melalui pengaturan nasional dan budaya yang berbeda yang menjadikan kepemilikan asing sebagai monitor yang lebih baik (Zraiq \& Fadzil, 2018). Ketika kondisi pemegang saham mayoritas adalah pihak asing, pihak asing berpotensi akan menempatkan orang asing agar menjabat pada posisi dewan komisaris atau dewan direksi (Wiranata \& Nugrahanti, 2013). Tujuan dari dilakukannya hal tersebut adalah agar tercapai tujuan yang selaras karena persamaan prinsip. Selain itu melalui kepemilikan asing kinerja keuangan perusahaan dapat ditingkatkan, hal ini karena adanya pengaruh positif antara keduanya (Astuti, Anisykurlillah, \& Murtini, 2014). Berdasarkan penjelasan tersebut penelitian ini merumuskan untuk hipotesis kedua adalah kepemilikan asing mempengaruhi kinerja perusahaan secara positif.

\subsection{Pengaruh Kepemilikan Keluarga terhadap Kinerja Perusahaan}

Kehadiran kepemilikan keluarga berdampak pada kinerja bank, yaitu mempengaruhi kinerja bank secara positif (Arouri, Hossain, \& Muttakin, 2014). Kepemilikan keluarga dianggap lebih efisien daripada kepemilikan publik, hal ini dikarenakan biaya pengawasan lebih rendah dan keluarga memiliki kepentingan untuk membuat keputusan dalam penciptaan nilai bagi perusahaan (Astuti et al., 2015). Pengaruh keluarga akan semakin kuat ketika anggota keluarga menjabat sebagai Chief Executive Officer (CEO), manajer puncak, ketua atau direktur perusahaan (Chu, 2011). Kepemilikan keluarga dapat berpengaruh besar terhadap perusahaan daripada eksekutif non 
keluarga. Kepemilikan keluarga yang dapat bertahan dalam jangka waktu yang lama dan berkelanjutan dimanfaatkan untuk melindungi anggota keluarganya dalam perusahaan. Kondisi tersebut memungkinkan keluarga memiliki motivasi menyerahkan bisnis mereka ke keluarga terdekat mereka dengan tujuan untuk melindungi reputasi nama keluarga (Zraiq \& Fadzil, 2018). Adanya kepemilikan keluarga dalam perusahaan juga dapat membantu mengurangi konflik keagenan. Hal ini dibuktikan dalam penelitian Purkayastha et al. (2019) yang menjelaskan kepemilikan keluarga yang dominan dapat mengurangi dampak negatif dari konflik antara manajer dan shareholders. Maka dapat dirumuskan hipotesis ketiga bahwa kepemilikan keluarga mempengaruhi kinerja perusahaan secara positif.

\subsection{Moderasi Corporate Governance atas Pengaruh dari Struktur Modal terhadap Kinerja Perusahaan}

Penerapan corporate governance menunjukkan kemampuan perusahaan dalam mengelola perusahaan, corporate governance yang kurang baik berpotensi pada kegagalan pengelolaan struktur modal dan menyebabkan kebangkrutan (Noviani et al., 2019). Corporate governance menjadi pedoman dalam menyelesaikan konflik yang terjadi antara manajer dan shareholders untuk memastikan bahwa manajer dapat mengelola dana sehingga dapat memaksimalkan nilai perusahaan. Perusahaan akan memiliki akses pendanaan eksternal lebih besar ketika proporsi komisaris independen sebagai corporate governance meningkat (Claessens \& Yurtoglu, 2013). Akses pendanaan eksternal yang lebih besar memberikan kemudahan bagi perusahaan dalam mengelola serta meningkatkan struktur modal dalam perusahaan. Selain itu, melalui adanya corporate governance yang diukur melalui kepemilikan manajerial, perusahaan dapat mengambil kebijakan terkait utang (Yanti, Sarwani, \& Rosari, 2021). Kemudahan dalam mengambil kebijakan utang oleh perusahaan diharapkan dapat menjadikan perusahaan lebih baik dalam mengelola struktur modal serta lebih mudah dalam mengambil keputusan selanjutnya untuk meningkatkan kinerja perusahaan. Hal tersebut mendukung penelitian Artini \& Diantini (2014) yang menjelaskan bahwa pemilihan pendanaan baik pendanaan internal maupun eksternal dapat dipengaruhi oleh struktur corporate governance. Uraian tersebut menjelaskan bahwa adanya peran corporate governance pada struktur modal. Maka dapat dirumuskan hipotesis keempat dari penelitian ini adalah corporate governance memoderasi pengaruh struktur modal terhadap kinerja perusahaan.

\subsection{Moderasi Corporate Governance atas Pengaruh dari Kepemilikan Asing terhadap Kinerja Perusahaan}

Corporate governance ditambahkan sebagai variabel moderasi karena penelitian tata kelola perusahaan di Indonesia masih memandang bahwa elemen penting dari kesuksesan tata kelola perusahaan adalah dengan adanya fungsi pengawasan (Ditta \& Setiawan, 2019). Corporate governance memberikan fungsi pengawasan yang efektif melalui komisaris independen yang diwujudkan dengan adanya pelaporan informasi keuangan yang andal sehingga memberikan dampak pada berkurangnya asimetri informasi (Setiawan, Adelisa, \& Ratri, 2020). Berkurangnya asimetri informasi mengartikan bahwa perusahaan menjadi lebih transparan terhadap pengungkapan informasi sehingga meningkatkan tingkat kepercayaan pemegang saham. Pihak asing sebagai pemilik perusahaan akan lebih mudah dalam mengawasi perusahaan melalui adanya transparansi pengungkapan informasi. Maka dapat dirumuskan hipotesis kelima dari penelitian ini yaitu corporate governance memoderasi kepemilikan asing terhadap kinerja perusahaan. 


\subsection{Moderasi Corporate Governance atas Pengaruh dari Kepemilikan Keluarga terhadap Kinerja Perusahaan}

Wairisal \& Hariyati (2021); Detthamrong, Chancharat, \& Vithessonthi` (2017) dalam penelitiannya menjelaskan bahwa corporate governance dapat menjadi salah satu cara memaksimalkan serta meningkatkan nilai perusahaan. Perusahaan perlu memperhatikan penerapan good corporate governance dalam perusahaan, karena melalui good corporate governance perusahaan mampu memenuhi kepercayaan masyarakat sebagai syarat perusahaan untuk berkembang (Purnamawati, Yuniarta, \& Astria, 2017). Kepemilikan keluarga dapat menjadi salah satu alternatif dalam mengurangi masalah keagenan, tetapi juga dapat menciptakan konflik antara pemilik saham yaitu pemilik saham mayoritas serta pemilik saham minoritas (Maury, 2006; Siagian, 2011; Purkayastha et al., 2019). Penerapan corporate governance dalam perusahaan akan memperkuat pengawasan terhadap manajemen, hal ini dikarenakan adanya transparansi informasi sehingga tidak terjadi asimetri informasi antara pengelola dan pemilik perusahaan maupun pemegang saham mayoritas dan minoritas. Berdasarkan uraian tersebut dapat dirumuskan hipotesis keenam yaitu corporate governance memoderasi kepemilikan keluarga terhadap kinerja perusahaan.

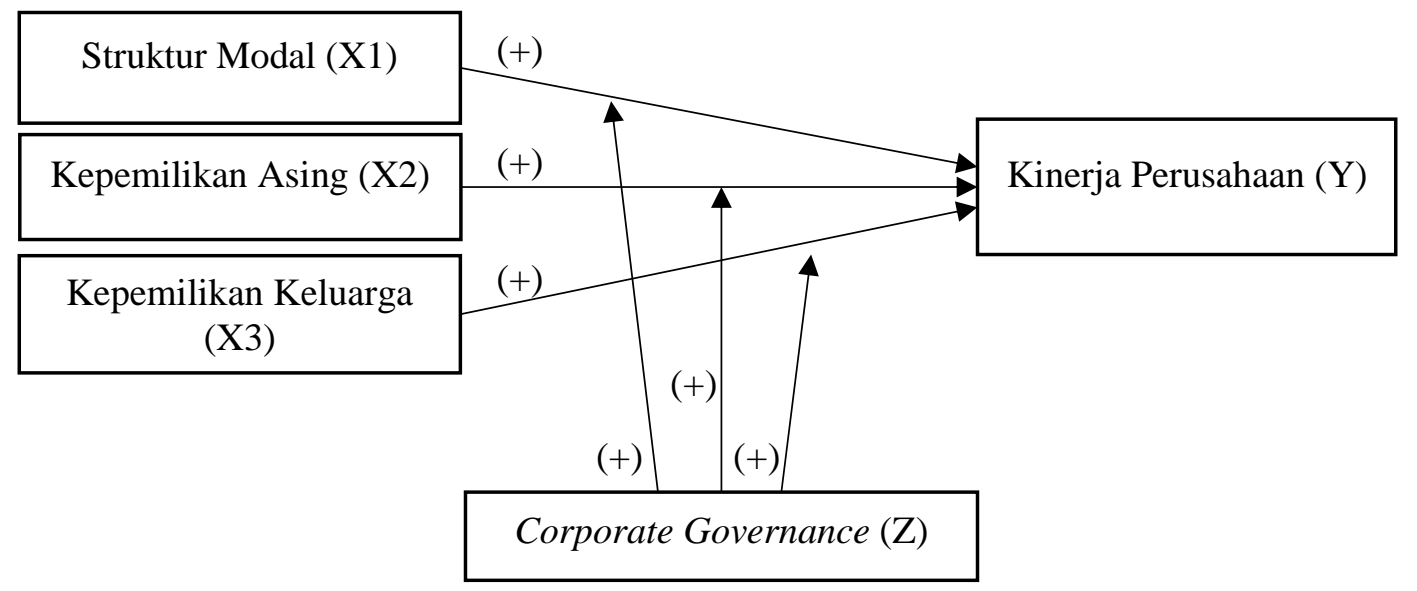

Gambar 1. Kerangka Penelitian

\section{METODE PENELITIAN}

Jenis data yang digunakan pada penelitian ini adalah data panel yaitu gabungan data time series dan cross section. Sumber data berasal dari Indonesian Capital Market Directory (ICMD) dan laporan keuangan tahunan. Populasi yang digunakan adalah seluruh perusahaan di sektor perdagangan, jasa dan investasi pada Bursa Efek Indonesia periode 2016-2019. Sampel pada penelitian ini ditentukan dari metode purposive sampling yaitu melalui persyaratan pemilihan sampel sebagai berikut: 
Tabel 2. Tabel Pemilihan Sampel

\begin{tabular}{ccc}
\hline & \multicolumn{1}{c}{ Persyaratan } & $\begin{array}{c}\text { Jumlah } \\
\text { Perusahaan }\end{array}$ \\
\hline 1 & $\begin{array}{l}\text { Perusahaan-perusahaan yang tercatat di BEI sektor perdagangan, jasa dan } \\
\text { investasi tahun 2016-2019 }\end{array}$ & 168 \\
2 & Memiliki data lengkap sesuai dengan kebutuhan penelitian ini & $(148)$ \\
3 & Laporan tahunan yang menerbitkan laporan menggunakan mata uang asing & $(1)$ \\
Jumlah sampel akhir & 19 \\
Tahun pengamatan & 4 \\
Jumlah pengamatan & 76 \\
\hline
\end{tabular}

Proksi Tobin's $q$ digunakan dalam penelitian ini sebagai proksi dari kinerja perusahaan. Proksi kepemilikan asing dan kepemilikan keluarga akan mewakili variabel struktur kepemilikan dan proksi DER mewakili variabel struktur modal. Corporate governance sebagai variabel moderasi akan diukur dengan tiga variabel yaitu komisaris independen, kepemilikan manajerial dan kepemilikan institusional. Tabel berikut disajikan untuk lebih menjelaskan pengukuran berbagai variabel dan indikator dalam penelitian ini.

Tabel 3. Variabel Penelitian

\begin{tabular}{|c|c|}
\hline Variabel & Indikator \\
\hline \multicolumn{2}{|l|}{ Dependen } \\
\hline Kinerja perusahaan (TOBIN's Q) & $\begin{array}{l}\text { Jumlah nilai pasar seluruh saham dengan total nilai utang } \\
\text { perusahaan dibagi dengan total aset perusahaan }\end{array}$ \\
\hline \multicolumn{2}{|l|}{ Independen } \\
\hline Struktur modal (DER) & $\begin{array}{l}\text { Total nilai utang perusahaan dibagi dengan total ekuitas } \\
\text { perusahaan }\end{array}$ \\
\hline Kepemilikan asing (FOOWN) & Jumlah saham pihak asing dibagi dengan total saham beredar \\
\hline Kepemilikan keluarga (FAOWN) & Jumlah saham keluarga dibagi dengan total saham beredar \\
\hline \multicolumn{2}{|l|}{ Moderasi } \\
\hline Komisaris Independen (KOMINDEP) & $\begin{array}{l}\text { Komisaris independen perusahaan dibagi dengan total } \\
\text { komisaris perusahaan }\end{array}$ \\
\hline Kepemilikan Manajerial (MOWN) & $\begin{array}{l}\text { Total saham yang dimiliki dewan direksi dibagi dengan total } \\
\text { saham beredar }\end{array}$ \\
\hline Kepemilikan Institusional (IOWN) & $\begin{array}{l}\text { Total saham yang dimiliki institusional dibagi dengan total } \\
\text { saham beredar }\end{array}$ \\
\hline \multicolumn{2}{|l|}{ Variabel Kontrol } \\
\hline Pertumbuhan Perusahaan (GROWTH) & $\begin{array}{l}\text { Selisih total pendapatan penjualan perusahaan periode sekarang } \\
\text { dan periode sebelumnya dibagi dengan pendapatan penjualan }\end{array}$ \\
\hline Struktur Aset (STRUCTURE) & $\begin{array}{l}\text { Total aset tetap perusahaan dibagi dengan total dari aset } \\
\text { perusahaan }\end{array}$ \\
\hline
\end{tabular}

Penelitian ini akan menguji dua variabel bebas yaitu struktur modal dan struktur kepemilikan dengan variabel terikatnya adalah kinerja perusahaan serta terdapat variabel moderasi yaitu corporate governance. Teknik analisis data adalah dengan statistik deskriptif, uji asumsi klasik, analisis regresi data panel, dan Moderated Regression Analysis (MRA). Penelitian ini akan menggunakan alat analisis yaitu Eviews 9.

Model regresi pada penelitian ini adalah sebagai berikut

$$
\begin{aligned}
& \text { TOBIN's } Q_{i t}=\alpha+\beta_{1} D E R_{i t}+\beta_{2} F_{O O O W N}+\beta_{3} F A O W N_{i t}+\varepsilon_{t} \\
& \text { TOBIN's } Q_{i t}=\alpha+\beta_{1} D E R_{i t}+\beta_{2} \text { FOOWN }_{i t}+\beta_{3} \text { FAOWN }{ }_{i t}+\beta_{4} \text { KOMINDEP }_{i t}+ \\
& \beta_{5} M O W N_{i t}+\beta_{6} I O W N_{i t}+\beta_{7} D E R_{i t} . K_{O M I N D E P_{i t}}+\beta_{8} D E R_{i t} \cdot M O W N_{i t}+
\end{aligned}
$$




$$
\begin{aligned}
& \beta_{9} D E R_{i t} . \text { IOWN }_{i t}+\beta_{10} \text { FOOWN }_{i t} \text {. KOMINDEP } i t+\beta_{11} \text { FOOWN }_{i t} . \text { MOWN }_{i t}+ \\
& \beta_{12} \text { FOOWN }_{i t} \text {.IOWN }+\beta_{13} \text { FAOWN } \text { It }_{\text {. KOMINDEP }}+\beta_{14} \text { FAOWN }{ }_{i t} . \text { MOWN + } \\
& \beta_{15} \text { FAOWN }_{i t} \text {. IOWN } \text { It }+\beta_{16} \text { GROWTH }_{i t}+\beta_{17} \text { STRUCTURE } E_{i t}+\varepsilon_{t}
\end{aligned}
$$

Keterangan :

$\begin{array}{ll}\text { TOBIN's } Q & =\text { kinerja perusahaan (market base), } \\ \text { DER } & =\text { struktur modal, } \\ \text { FOOWN } & =\text { kepemilikan asing, } \\ \text { FAOWN } & =\text { kepemilikan keluarga, } \\ \text { KOMINDEP } & =\text { komisaris independen, } \\ \text { MOWN } & =\text { kepemilikan manajerial, } \\ \text { IOWN } & =\text { kepemilikan institusional, } \\ \text { GROWTH } & =\text { pertumbuhan perusahaan, } \\ \text { STRUCTURE } & =\text { struktur aset, } \\ \alpha & =\text { konstanta, } \\ \beta 1-\beta 17 & =\text { koefisien regresi (beta), } \\ \varepsilon & =\text { error term. }\end{array}$

\section{HASIL DAN PEMBAHASAN}

Statistik deskriptif menunjukkan nilai rata-rata, nilai maksimum dan minimum dari 76 sampel perusahaan dalam penelitian ini. Tabel 4 berikut ini menunjukkan hasil statistik deskriptif 76 sampel pada penelitian ini.

Tabel 4. Statistik Deskriptif

\begin{tabular}{lccccc}
\hline \multicolumn{1}{c}{ Variabel } & $\begin{array}{c}\text { Jumlah } \\
\text { Observasi }\end{array}$ & $\begin{array}{c}\text { Nilai } \\
\text { Rata-rata }\end{array}$ & $\begin{array}{c}\text { Standar } \\
\text { Deviasi }\end{array}$ & $\begin{array}{c}\text { Nilai } \\
\text { Min }\end{array}$ & $\begin{array}{c}\text { Nilai } \\
\text { Max }\end{array}$ \\
\hline TOBIN's Q (x) & 76 & 1,47 & 0,94 & 0,35 & 5,64 \\
DER (x) & 76 & 1,03 & 110,8 & $-1,88$ & 4,29 \\
FOOWN (\%) & 76 & 37,56 & 36,8 & 0,00 & 153,71 \\
FAOWN (\%) & 76 & 4,62 & 11,1 & 0,00 & 43 \\
KOMINDEP (\%) & 76 & 38,61 & 7,82 & 25 & 50 \\
MOWN (\%) & 76 & 2,67 & 7,31 & 0,00 & 31,89 \\
IOWN (\%) & 76 & 55,61 & 27,23 & 0,00 & 94,25 \\
GROWTH (\%) & 76 & 0,56 & 45,24 & $-259,33$ & 47,7 \\
STRUCTURE (\%) & 76 & 44,9 & 34,16 & 0,14 & 201,56 \\
\hline
\end{tabular}

Nilai Tobin's $q$ pada Tabel 4 menunjukkan nilai rata-rata sebesar 1,47, artinya kinerja perusahaan memiliki nilai rata-rata kapitalisasi pasar saham dan utang sebesar 1,47 kali dari jumlah total buku aktiva. Nilai rata-rata dari DER menunjukkan nilai sebesar 1,03, artinya struktur modal perusahaan memiliki nilai utang sebesar 1,03 kali dari nilai ekuitasnya. Kepemilikan perusahaan yang diukur dari kepemilikan asing dan kepemilikan keluarga menunjukkan nilai rata-rata sebesar $37,56 \%$ dan 4,62\%. Kepemilikan asing memiliki nilai rata-rata sebesar 37,56\%, artinya saham yang diobservasi secara rata-rata dimiliki oleh investor asing adalah sebesar 37,56\%. Kepemilikan keluarga memiliki nilai rata-rata sebesar $4,62 \%$, artinya saham yang diobservasi secara umum dimiliki oleh keluarga pendiri adalah sebesar $4,62 \%$.

Nilai rata-rata dari komisaris independen menunjukkan nilai sebesar $38,61 \%$, artinya saham yang diobservasi secara rata-rata dimiliki oleh komisaris independen adalah sebesar $38,61 \%$. Kepemilikan institusional menunjukkan nilai rata-rata yang sangat tinggi yaitu sebesar $55,61 \%$, artinya saham yang diobservasi secara rata-rata dimiliki oleh institusi adalah sebesar 
$55,61 \%$. Sedangkan nilai rata-rata kepemilikan manajerial pada penelitian ini menunjukkan nilai sebesar 2,67\% , artinya besar nilai saham manajemen dalam perusahaan yang diobservasi secara rata-rata adalah $2,67 \%$. Nilai rata-rata dari pertumbuhan perusahaan menunjukkan nilai $0,56 \%$. Artinya perusahaan mengalami pertumbuhan secara rata-rata sebesar $0,56 \%$. Struktur aset perusahaan industri, jasa dan keuangan pada penelitian ini memiliki nilai rata-rata sebesar $44,9 \%$. Artinya struktur aset perusahaan memiliki total aset tetap sebesar $44,9 \%$ dari total aset perusahaan.

Pemilihan model pada regresi diperlukan untuk mendapatkan model estimasi yang terbaik. Pemilihan model estimasi pada penelitian ini menggunakan uji chow dan uji hausman yang hasil kedua uji tersebut ditunjukkan pada Tabel 5.

Tabel 5. Hasil Uji Pemilihan Metode Estimasi

\begin{tabular}{lcc}
\hline & Uji Chow & Uji Hausman \\
\hline $\mathrm{F}$ & 0,0000 & \\
Chi square & & 26,762 \\
Prob & $0,0000^{*}$ & $0,0001^{*}$ \\
Keputusan model estimasi & Fixed Effect & Fixed Effect \\
\hline *sig. $\alpha=1 \%$ & &
\end{tabular}

Tabel 5 menunjukkan hasil dari probabilitas cross section $\mathrm{F}$ 0,0000 dimana nilai tersebut kurang dari 0,05. Maka metode estimasi yang dipilih berdasarkan hasil uji chow adalah fixed effect. Selanjutnya, pada uji hausman nilai probabilitas menunjukkan nilai $0,0001<0,05$, artinya metode estimasi akhir yang dipilih adalah fixed effect.

Pengujian normalitas data penelitian diperlukan untuk mengetahui apakah data tersebut berdistribusi normal. Pengujian normalitas dapat dilihat dari nilai probabilitas Jarque-Bera. Hasil uji normalitas pada kedua model menunjukkan data penelitian berdistribusi normal. Pada model satu nilai probabilitas menghasilkan nilai $0,27>0,05$ dan pada model dua nilai probabilitas menghasilkan nilai $0,58>0,05$.

\begin{tabular}{|ccc}
\multicolumn{3}{c}{ Tabel 6. Hasil Uji Normalitas } \\
\hline & Model 1 & Model 2 \\
\hline Jarque-Bera & 2,63 & 1,10 \\
Prob & 0,27 & 0,58 \\
\hline
\end{tabular}

Uji multikolinearitas pada penelitian ini adalah dengan menganalisis nilai Variance Inflation Factors (VIF). Tabel 7 menunjukkan uji multikolinearitas model regresi 1 dan 2. Hasil uji dengan menggunakan VIF menunjukkan bahwa nilai VIF model regresi satu seluruhnya memiliki nilai $<10$. Artinya tidak terjadi masalah pada uji multikolinearitas model regresi satu. Sedangkan pada model regresi dua menunjukkan bahwa beberapa nilai VIF memiliki nilai lebih dari 10, yaitu pada variabel efek utama dan variabel efek interaksi. Hal ini menjelaskan bahwa terjadi masalah multikolinearitas pada model regresi dua. Hasil yang sama ditunjukkan pada penelitian Purnamawati et al. (2017), menyebutkan bahwa adanya multikolinearitas tidak menjadi masalah karena model regresi tersebut merupakan model persamaan untuk moderasi. 
Tabel 7. Uji Multikolinearitas dengan VIF Model Regresi 2

\begin{tabular}{lcc}
\hline \multicolumn{1}{c}{ Variabel } & $\begin{array}{c}\text { VIF } \\
\text { Model 1 }\end{array}$ & $\begin{array}{c}\text { VIF } \\
\text { Model 2 }\end{array}$ \\
\hline DER & 1,23 & 119,53 \\
FOOWN & 1,02 & 115,62 \\
FAOWN & 1,45 & 108,79 \\
KOMINDEP & - & 12,56 \\
MOWN & - & 8,03 \\
IOWN & - & 7,92 \\
DER_KOMINDEP & - & 95,15 \\
DER_MOWN & - & 4,73 \\
DER_IOWN & - & 10,69 \\
FOOWN_KOMINDEP & - & 101,05 \\
FOOWN_MOWN & - & 2,36 \\
FOOWN_IOWN & - & 8,27 \\
FAOWN_KOMINDEP & - & 80,18 \\
FAOWN_MOWN & - & 5,35 \\
FAOWN_IOWN & - & 4,65 \\
GROWTH & 1,29 & 2,22 \\
STRUCTURE & 1,24 & 1,66 \\
\hline
\end{tabular}

Uji heteroskedastisitas pada uji asumsi klasik digunakan untuk menguji ketidaksamaan varian dari residual satu pengamatan ke pengamatan yang lain, jika terdapat perbedaan maka disimpulkan bahwa terdapat heteroskedastisitas dan apabila tetap disebut dengan homoskedastisitas. Dari pengujian ini yang diharapkan adalah tidak terjadi heteroskedastisitas.

Tabel 8. Uji Heteroskedastisitas Model Regresi 2

\begin{tabular}{lcc}
\hline \multicolumn{1}{c}{ Variabel } & $\begin{array}{c}\text { Prob. } \\
\text { Model 1 }\end{array}$ & $\begin{array}{c}\text { Prob. } \\
\text { Model 2 }\end{array}$ \\
\hline C & 0,00 & 0,47 \\
DER & 0,61 & 0,38 \\
FOOWN & 0,95 & 0,34 \\
FAOWN & 1,00 & 0,44 \\
KOMINDEP & 0,40 & 0,35 \\
MOWN & 0,06 & 0,46 \\
IOWN & - & 0,78 \\
DER_KOMINDEP & - & 0,54 \\
DER_MOWN & - & 0,97 \\
DER_IOWN & - & 0,86 \\
FOOWN_KOMINDEP & - & 0,27 \\
FOOWN_MOWN & - & 0,92 \\
FOOWN_IOWN & - & 0,67 \\
FAOWN_KOMINDEP & - & 0,21 \\
FAOWN_MOWN & - & 0,65 \\
FAOWN_IOWN & - & 0,17 \\
GROWTH & 0,40 & 0,81 \\
STRUCTURE & 0,06 & 0,33 \\
\hline
\end{tabular}

Data dinyatakan tidak terdapat heteroskedastisitas apabila probabilitas $>0,05$. Pada model regresi satu maupun model regresi dua tidak ditemukan adanya masalah heteroskedastisitas karena nilai probabilitas $>0,05$ yang ditunjukkan pada Tabel 8 .

Hasil uji regresi data panel pada penelitian ini menggunakan pendekatan model fixed effect. Hasil pengujian regresi model satu dengan pendekatan model fixed effect dapat dilihat pada Tabel 9. 
Tabel 9. Hasil Estimasi Fixed Effect Model Regresi 1

\begin{tabular}{ccl}
\hline Variabel & Koefisien & Prob. \\
\hline C & 1,321 & $0,000^{* *}$ \\
DER & 0,290 & $0,022^{*}$ \\
FOOWN & $-0,087$ & 0,691 \\
FAOWN & 0,514 & 0,743 \\
GROWTH & $-0,104$ & 0,588 \\
STRUCTURE & $-0,309$ & 0,299 \\
\hline R-squared & & 0,884 \\
Adjusted $R$-squared & 0,832 \\
**sig. $\alpha=1 \%$; sig. $\alpha=5 \%$ &
\end{tabular}

Hasil koefisien regresi pada Tabel 9 menunjukkan nilai koefisien DER dan FAOWN mempunyai nilai koefisien positif, artinya ketika DER dan FAOWN bertambah satu satuan maka Tobin's $q$ juga akan bertambah sama dengan nilai koefisien regresi. Hasil koefisien regresi dari FOOWN menunjukkan nilai negatif, artinya ketika FOOWN bertambah satu satuan maka Tobin's $q$ akan berkurang sama dengan nilai koefisien regresi. Nilai probabilitas DER adalah $0,022<0,05$ dengan koefisien bernilai positif 0,290 . Nilai tersebut membuktikan bahwa struktur modal dalam penelitian ini terbukti berpengaruh positif terhadap kinerja perusahaan. Sedangkan, nilai probabilitas dari FOOWN dan FAOWN menunjukkan nilai probabilitas $>0,05$. Artinya, variabel kepemilikan asing dan kepemilikan keluarga tidak berpengaruh signifikan terhadap kinerja perusahaan. Hasil estimasi fixed effect menghasilkan nilai adjusted $r$ square yaitu 0,832. Artinya terdapat pengaruh sebesar $83,2 \%$ dari variabel bebas terhadap kinerja perusahaan dan sisanya dipengaruhi oleh variabel lain.

Nilai koefisien dari hasil pengujian efek moderasi yaitu DER, KOMINDEP, DER_KOMINDEP, MOWN menunjukkan nilai positif. Artinya ketika variabel efek moderasi DER, KOMINDEP, DER_KOMINDEP, MOWN bertambah satu satuan maka kinerja perusahaan juga bertambah sama dengan nilai koefisien regresi. Sedangkan, nilai koefisien dari DER_MOWN, IOWN, DER_IOWN menunjukkan nilai negatif, artinya ketika variabel DER_MOWN, IOWN, DER_IOWN bertambah satu satuan maka kinerja perusahaan akan berkurang sama dengan nilai koefisien regresi.

Nilai probabilitas variabel KOMINDEP adalah 0,240 dengan nilai DER_KOMINDEP 0,941. Nilai probabilitas dari MOWN adalah 0,062 dan DER_MOWN adalah 0,755. Nilai tersebut menunjukkan variabel komisaris independen dan kepemilikan manajerial pada uji ini bukan merupakan variabel moderasi. Sedangkan, nilai probabilitas dari IOWN adalah sebesar 0,699 dengan nilai DER_IOWN adalah 0,001. Hal ini menunjukkan variabel kepemilikan institusional merupakan pure moderator. Variabel interaksi DER_KOMINDEP dan DER_MOWN menunjukkan nilai probabilitas $>0,05$ artinya tidak terdapat pengaruh DER_KOMINDEP dan DER_MOWN dalam memoderasi hubungan struktur modal terhadap kinerja perusahaan. Sedangkan variabel interaksi DER_IOWN menunjukkan nilai probabilitas $<0,05$ dengan koefisien -1,271. Artinya variabel interaksi DER_IOWN berpengaruh negatif dan signifikan terhadap hubungan struktur modal dengan kinerja perusahaan. 
Tabel 10. Hasil Uji MRA dengan Corporate Governance Memoderasi Pengaruh Struktur Modal terhadap Kinerja Perusahaan

\begin{tabular}{|c|c|c|c|c|c|c|}
\hline \multirow{2}{*}{ Variabel } & \multicolumn{2}{|c|}{$\begin{array}{c}\text { DER } \\
\text { KOMINDEP }\end{array}$} & \multicolumn{2}{|c|}{ DER_MOWN } & \multicolumn{2}{|c|}{ DER_IOWN } \\
\hline & Koefisien & Prob. & Koefisien & Prob. & Koefisien & Prob. \\
\hline $\mathrm{C}$ & 0,680 & 0,230 & 0,999 & $0,000 * * *$ & 2,065 & $\begin{array}{c}0,000 * * \\
*\end{array}$ \\
\hline DER & 0,242 & 0,378 & 0,337 & $0,011^{* *}$ & 0,548 & $\begin{array}{c}0,000 * * \\
*\end{array}$ \\
\hline KOMINDEP & 1,766 & 0,240 & - & - & - & - \\
\hline MOWN & - & - & 5,740 & $0,062 *$ & & \\
\hline IOWN & - & - & - & - & $-0,266$ & 0,699 \\
\hline DER_KOMINDEP & 0,052 & 0,941 & - & - & - & - \\
\hline DER_MOWN & - & - & $-2,026$ & 0,755 & - & - \\
\hline DER_IOWN & - & - & - & - & $-1,271$ & $0,001 * *$ \\
\hline GROWTH & $-0,119$ & 0,503 & $-0,011$ & 0,949 & $-0,153$ & 0,337 \\
\hline STRUCTURE & $-0,360$ & 0,219 & 0,003 & 0,991 & $-0,496$ & $0,063^{*}$ \\
\hline$R$-squared & & 0,888 & & 0,895 & & 0,910 \\
\hline Adj. R-squared & & 0,838 & & 0,850 & & 0,871 \\
\hline
\end{tabular}

Nilai adjusted $R$ square pada Tabel 10 menunjukkan nilai 0,$838 ; 0,850 ; 0,871$. Hal tersebut menjelaskan terdapat pengaruh sebesar rata-rata $85 \%$ dari variabel bebas DER, KOMINDEP, MOWN, IOWN, DER_KOMINDEP, DER_MOWN, dan DER_IOWN terhadap Tobin's $q$ dan sisanya dipengaruhi oleh variabel lain.

Tabel 11. Hasil Uji MRA dengan Corporate Governance Memoderasi Pengaruh Kepemilikan Asing terhadap Kinerja Perusahaan

\begin{tabular}{|c|c|c|c|c|c|c|}
\hline \multirow{2}{*}{ Variabel } & \multicolumn{2}{|c|}{$\begin{array}{c}\text { FOOWN_- } \\
\text { KOMINDEP }\end{array}$} & \multicolumn{2}{|c|}{ FOOWN_MOWN } & \multicolumn{2}{|c|}{ FOOWN_IOWN } \\
\hline & Koefisien & Prob. & Koefisien & Prob. & Koefisien & Prob. \\
\hline $\mathrm{C}$ & 1,046 & $0,084 *$ & 1,390 & $\begin{array}{c}0,000 \\
* *\end{array}$ & 2,782 & $\begin{array}{c}0,000^{*} \\
*\end{array}$ \\
\hline FOOWN & $-0,884$ & 0,429 & 0,060 & 0,799 & $-0,604$ & 0,225 \\
\hline KOMINDEP & 1,607 & 0,306 & - & - & - & - \\
\hline MOWN & - & - & 4,371 & $0,057 *$ & - & - \\
\hline IOWN & - & - & - & - & $-1,893$ & $0,073^{*}$ \\
\hline FOOWN_KOMINDEP & 1,991 & 0,465 & - & - & - & - \\
\hline FOOWN_MOWN & - & - & $-0,911$ & 0,750 & - & - \\
\hline FOOWN_IOWN & - & - & - & - & 0,935 & 0,262 \\
\hline GROWTH & $-0,116$ & 0,530 & $-0,021$ & 0,910 & $-0,081$ & 0,660 \\
\hline STRUCTURE & $-0,377$ & 0,216 & $-0,117$ & 0,724 & $-0,410$ & 0,179 \\
\hline$R$-squared & & 0,880 & & 0,880 & & 0,879 \\
\hline Adj. R-squared & & 0,830 & & 0,827 & & 0,825 \\
\hline
\end{tabular}

**sig. $1 \%$; * sig. $10 \%$

Nilai koefisien dari hasil pengujian efek moderasi yaitu KOMINDEP, FOOWN_KOMINDEP, MOWN, dan FOOWN_IOWN, FOOWN pada pengujian efek moderasi kepemilikan manajerial menunjukkan nilai positif, artinya ketika variabel-variabel tersebut bertambah satu satuan maka kinerja perusahaan juga bertambah sama dengan nilai koefisien regresi. Sedangkan nilai koefisien FOOWN_MOWN, IOWN, FOOWN pada pengujian efek moderasi komisaris independen dan kepemilikan institusional menunjukkan nilai koefisien negatif, artinya ketika variabel-variabel tersebut bertambah satu satuan maka kinerja perusahaan akan berkurang sebesar nilai koefisien regresi tersebut. 
Nilai probabilitas variabel KOMINDEP adalah 0,306 dengan FOOWN_KOMINDEP sebesar 0,465. Nilai probabilitas dari MOWN adalah sebesar 0,057 dengan FOOWN_MOWN adalah sebesar 0,750. Nilai probabilitas dari IOWN adalah sebesar 0,073 dengan FOOWN_IOWN adalah sebesar 0,262. Artinya ketiga proksi dari corporate governance tersebut pada uji ini bukan merupakan variabel moderasi. Nilai probabilitas yang ditunjukkan pada FOOWN_KOMINDEP, FOOWN_MOWN dan FOOWN_IOWN menunjukkan nilai probabilitas > 0,05 yang menjelaskan bahwa variabel kepemilikan asing yang dimoderasi dengan corporate governance tidak berpengaruh signifikan terhadap kinerja perusahaan.

Nilai adjusted $R$ square pada Tabel 11 menunjukkan nilai sebesar 0,830;0,827; 0,825. Hal tersebut menjelaskan terdapat pengaruh sebesar rata-rata $83 \%$ dari variabel bebas FOOWN, KOMINDEP, MOWN, IOWN, FOOWN_KOMINDEP, FOOWN_MOWN, dan FOOWN_IOWN terhadap Tobin's $q$ dan sisanya dipengaruhi oleh variabel lain.

Tabel 12. Hasil Uji MRA dengan Corporate Governance Memoderasi Pengaruh Kepemilikan Keluarga terhadap Kinerja Perusahaan

\begin{tabular}{|c|c|c|c|c|c|c|}
\hline \multirow{2}{*}{ Variabel } & \multicolumn{2}{|c|}{$\begin{array}{l}\text { FAOWN_- } \\
\text { KOMINDEP }\end{array}$} & \multicolumn{2}{|c|}{ FAOWN_MOWN } & \multicolumn{2}{|c|}{ FAOWN_IOWN } \\
\hline & Koefisien & Prob. & Koefisien & Prob. & Koefisien & Prob. \\
\hline $\mathrm{C}$ & 1,373 & $0,023 * *$ & 1,220 & $0,000 * * *$ & 2,250 & $0,000 * * *$ \\
\hline FAOWN & $-4,372$ & 0,148 & 5,509 & 0,475 & $-5,974$ & 0,499 \\
\hline KOMINDEP & 0,639 & 0,670 & - & - & - & - \\
\hline MOWN & - & - & 4,263 & $0,059 *$ & - & - \\
\hline IOWN & - & - & - & - & $-0,969$ & 0,213 \\
\hline FAOWN_KOMINDEP & 12,178 & $0,063 *$ & - & - & - & - \\
\hline FAOWN_MOWN & - & - & $-16,832$ & 0,502 & - & - \\
\hline FAOWN_IOWN & - & - & - & - & 18,419 & 0,470 \\
\hline GROWTH & $-0,147$ & 0,442 & $-0,044$ & 0,822 & $-0,071$ & 0,725 \\
\hline STRUCTURE & $-0,385$ & 0,191 & $-0,102$ & 0,754 & $-0,389$ & 0,204 \\
\hline$R$-squared & & 0,886 & & 0,881 & & 0,877 \\
\hline Adj. R-squared & & 0,836 & & 0,829 & & 0,822 \\
\hline
\end{tabular}

Nilai koefisien dari hasil pengujian efek moderasi yaitu KOMINDEP, FAOWN_KOMINDEP, MOWN, dan FAOWN_IOWN, FAOWN pada pengujian efek moderasi kepemilikan manajerial menunjukkan nilai positif, artinya ketika variabel-variabel tersebut bertambah satu satuan maka kinerja perusahaan juga bertambah sama dengan nilai koefisien regresi. Sedangkan nilai koefisien FAOWN_MOWN, IOWN, FAOWN pada pengujian efek moderasi komisaris independen dan kepemilikan institusional menunjukkan nilai koefisien negatif, artinya ketika variabel-variabel tersebut bertambah satu satuan maka kinerja perusahaan akan berkurang sebesar nilai koefisien regresi tersebut.

Nilai probabilitas variabel KOMINDEP adalah 0,670 dengan nilai FAOWN_KOMINDEP 0,063 . Nilai tersebut menunjukkan bahwa variabel komisaris independen merupakan variabel pure moderator. Nilai probabilitas dari MOWN adalah sebesar 0,059 dengan nilai FOOWN_MOWN adalah sebesar 0,502. Nilai probabilitas dari IOWN adalah sebesar 0,213 dengan nilai FAOWN_IOWN adalah sebesar 0,470. Nilai tersebut menunjukkan bahwa variabel kepemilikan manajerial dan kepemilikan institusional pada uji ini bukan merupakan variabel moderasi. Variabel interaksi FAOWN_MOWN dan FAOWN_IOWN menunjukkan nilai probabilitas $>0,05$, artinya tidak terdapat pengaruh FAOWN_MOWN dan FAOWN_IOWN dalam memoderasi hubungan 
kepemilikan keluarga terhadap kinerja perusahaan. Sedangkan variabel interaksi FAOWN_KOMINDEP menunjukkan nilai probabilitas < 0,10 dengan nilai koefisien 12,178. Artinya terdapat pengaruh positif variabel interaksi FAOWN_KOMINDEP terhadap hubungan kepemilikan keluarga dengan kinerja perusahaan.

Nilai adjusted $R$ square pada Tabel 12 menunjukkan nilai 0,836; 0,829; 0,822. Hal tersebut menjelaskan terdapat pengaruh sebesar rata-rata 83\% dari variabel bebas FAOWN, KOMINDEP, MOWN, IOWN, FAOWN_KOMINDEP, FAOWN_MOWN, dan FAOWN_IOWN terhadap Tobin's $q$ dan sisanya dipengaruhi oleh variabel lain.

\section{Pengaruh Struktur Modal terhadap Kinerja Perusahaan}

Penelitian ini menemukan adanya pengaruh positif dari struktur modal terhadap kinerja perusahaan yang ditunjukkan dari nilai probabilitas DER sebesar 0,0216 dengan koefisien 0,2897. Hasil tersebut mendukung penelitian Haryono et al. (2017) dan Detthamrong et al. (2017) bahwa kinerja perusahaan dapat dipengaruhi secara positif oleh struktur modal. Penelitian ini menemukan bahwa penggunaan utang pada perusahaan sektor perdagangan, jasa dan investasi memberikan manfaat bagi perusahaan untuk meningkatkan kinerja perusahaan. Hal ini dikarenakan utang akan memberikan manfaat dari pajak, sehingga perusahaan dapat memaksimalkan laba perusahaan. Haryono et al. (2017) menyebutkan bahwa penggunaan utang untuk kinerja perusahaan akan memberikan pengaruh positif tetapi setelah melewati titik optimal penggunaan utang, utang akan memberikan efek negatif. Hal ini menjelaskan bahwa penggunaan utang pada sektor perdagangan, jasa, dan investasi masih dibawah titik optimal penggunaan utang sehingga masih memberikan pengaruh positif bagi perusahaan. Selain itu, penggunaan utang juga dapat memberikan fungsi pengawasan bagi perusahaan. Hal ini dikarenakan pengelola akan lebih berhati-hati dalam mengambil kebijakan terkait struktur modal agar struktur modal tetap dapat berperan untuk meningkatkan kinerja perusahaan.

\section{Pengaruh Kepemilikan Asing terhadap Kinerja Perusahaan}

Hasil uji pada regresi data panel menunjukkan bahwa nilai koefisien FOOWN yang diproksikan sebagai kepemilikan asing menunjukkan nilai -0,087 dan probabilitas 0,691. Artinya kepemilikan asing tidak berpengaruh signifikan terhadap kinerja perusahaan. Hasil penelitian dari Dewata, Jauhari, Sari, \& Jumarni (2018) dan Rahmawati \& Handayani (2017) sejalan dengan temuan pada penelitian ini bahwa tidak terdapat pengaruh yang signifikan antara kepemilikan asing terhadap kinerja perusahaan. Berdasarkan statistik deskriptif kepemilikan asing menunjukkan nilai rata-rata $37,56 \%$ dan nilai minimum $0,00 \%$. Meskipun terdapat kepemilikan asing yang cukup tinggi, hal ini masih belum mampu mempengaruhi kinerja perusahaan. Hal tersebut dikarenakan masih ada beberapa perusahaan yang dijadikan sampel tidak memiliki kepemilikan asing dan hal ini mempengaruhi hasil dari penelitian. Selain itu, ada kemungkinan bahwa pihak asing tidak cocok dengan kelembagaan lokal (Carney et al., 2019) dan memilih untuk mempercayakan pengendalian perusahaan, serta tidak ikut serta dalam pengambilan keputusan perusahaan (Mollah, Farooque, \& Karim, 2012).

\section{Pengaruh Kepemilikan Keluarga terhadap Kinerja Perusahaan}

Nilai koefisien FAOWN yang diproksikan sebagai kepemilikan keluarga menunjukkan nilai 0,514 dan probabilitas 0,743 . Artinya tidak terdapat pengaruh yang signifikan antara kepemilikan keluarga terhadap kinerja perusahaan. Hasil ini tidak sesuai dengan rumusan hipotesis 
H3 yang merumuskan kepemilikan keluarga memiliki pengaruh positif terhadap kinerja perusahaan. Hasil ini mendukung hasil penelitian dari Rahmawati \& Handayani (2017) dan Sacristán-Navarro et al. (2011), yaitu tidak terdapat pengaruh antara kepemilikan keluarga dengan kinerja perusahaan. Hasil ini diperkuat dengan hasil statistik deskriptif yang menunjukkan bahwa rata-rata kepemilikan keluarga pada sampel penelitian yang digunakan nilainya rendah yaitu sebesar $4,62 \%$ dengan nilai minimum $0,00 \%$. Artinya terdapat beberapa perusahaan pada sampel penelitian tidak memiliki kepemilikan keluarga sehingga hal ini berpengaruh pada hasil penelitian.

\section{Moderasi Corporate Governance atas Pengaruh dari Struktur Modal terhadap Kinerja Perusahaan}

Nilai probabilitas komisaris independen, kepemilikan manajerial, dan kepemilikan institusional pada Tabel 10 menunjukkan nilai sebesar 0,941; 0,755; 0,001 dengan koefisien 0,052; $-2,026 ;-1,271$. Artinya corporate governance oleh proksi komisaris independen dan kepemilikan manajerial tidak memoderasi pengaruh antara struktur modal terhadap kinerja perusahaan. Hasil ini tidak sesuai dengan rumusan hipotesis pada $\mathrm{H} 4$ yang menyatakan bahwa corporate governance memperkuat pengaruh antara struktur modal terhadap kinerja perusahaan. Hasil temuan yang sejalan dengan penelitian ini terdapat pada penelitian Noviani et al. (2019) bahwa corporate governance belum mampu memoderasi pengaruh antara struktur modal terhadap kinerja perusahaan. Variabel moderasi kepemilikan institusional pada penelitian ini berpengaruh signifikan terhadap hubungan struktur modal dengan kinerja perusahaan namun menunjukkan nilai koefisien negatif. Artinya variabel moderasi kepemilikan institusional mampu memoderasi pengaruh struktur modal terhadap kinerja perusahaan. Kepemilikan institusional sebagai variabel moderasi pada penelitian ini menunjukkan nilai yang cukup tinggi, artinya kepemilikan institusional pada penelitian ini adalah sebagai kepemilikan mayoritas. Ketika porsi kepemilikan institusional tinggi maka akan meningkatkan corporate governance dan menggantikan fungsi pengawasan dari utang (Chung \& Zhang, 2011). Sehingga hal ini dapat berpengaruh memperlemah hubungan struktur modal terhadap kinerja perusahaan.

\section{Moderasi Corporate Governance atas Pengaruh dari Kepemilikan Asing terhadap Kinerja Perusahaan}

Berdasarkan hasil uji moderasi pada penelitian ini ditemukan bahwa ketiga proksi dari corporate governance menghasilkan nilai probabilitas $>0,05$ dan $>0,10$. Artinya moderasi corporate governance tidak mampu memoderasi pengaruh kepemilikan asing terhadap kinerja perusahaan. Hasil tersebut tidak sesuai dengan rumusan hipotesis H5 yang menyatakan bahwa corporate governance memperkuat pengaruh antara kepemilikan asing terhadap kinerja perusahaan. Hasil statistik deskriptif menunjukkan bahwa sebagian besar kepemilikan saham pada sampel penelitian merupakan kepemilikan terkonsentrasi. Kondisi tersebut dapat menyebabkan kepemilikan mayoritas mengeluarkan kebijakan sesuai dengan kepentingannya dan mengabaikan pemegang saham lainnya, baik pemegang saham mayoritas maupun asing (Heder \& Priyadi, 2017).

\section{Moderasi Corporate Governance atas Pengaruh dari Kepemilikan Keluarga terhadap Kinerja Perusahaan}

Nilai koefisien dari komisaris independen, kepemilikan manajerial, dan kepemilikan institusional sebagai proksi dari variabel moderasi corporate governance menunjukkan nilai 12,$178 ;-16,832 ; 18,419$ dengan nilai probabilitas 0,$063 ; 0,502 ; 0,470$. Artinya komisaris independen sebagai variabel moderasi mampu memoderasi pengaruh kepemilikan keluarga 
terhadap kinerja perusahaan. Hasil tersebut menunjukkan kesesuaian dengan rumusan hipotesis H6 pada penelitian ini, yang menyatakan bahwa corporate governance sebagai variabel moderasi mampu memperkuat pengaruh antara kepemilikan keluarga terhadap kinerja perusahaan. Adanya peran pengawasan oleh komisaris independen membuat pengawasan dari kepemilikan keluarga semakin efektif. Nilai rata-rata dari komisaris independen cukup besar yaitu 38,61\%, dimana semakin besar proporsi pengawasan oleh komisaris independen akan membuat pengawasan dalam perusahaan semakin efektif (Agustin \& Oktavianna, 2019) sehingga hal tersebut memperkuat pengaruh kepemilikan keluarga terhadap kinerja perusahaan.

\section{SIMPULAN DAN REKOMENDASI}

Tujuan dari penelitian ini adalah menganalisis pengaruh antara struktur modal dan struktur kepemilikan terhadap kinerja perusahaan, dengan dimoderasi oleh variabel corporate governance. Penelitian ini menemukan bahwa struktur modal dapat memberikan pengaruh positif terhadap kinerja perusahaan karena adanya manfaat pajak serta adanya peran utang sebagai pengawasan bagi perusahaan. Sedangkan struktur kepemilikan asing dan kepemilikan keluarga dalam penelitian ini masih belum mampu mempengaruhi kinerja perusahaan, karena adanya sampel kepemilikan yang bernilai nol. Hasil uji variabel kepemilikan institusional memoderasi hubungan struktur modal terhadap kinerja perusahaan, menunjukkan hasil sebagai variabel pure moderator dan bernilai negatif. Artinya kepemilikan institusional sebagai variabel moderasi memperlemah hubungan struktur modal terhadap kinerja perusahaan. Hal ini dikarenakan porsi kepemilikan institusional pada penelitian ini tinggi, dimana porsi kepemilikan institusional yang tinggi akan meningkatkan corporate governance dan menggantikan fungsi pengawasan dari utang. Sedangkan hasil uji variabel komisaris independen memoderasi hubungan kepemilikan keluarga terhadap kinerja perusahaan, menunjukkan hasil sebagai variabel pure moderator dan bernilai positif. Artinya variabel komisaris independen mampu memoderasi hubungan kepemilikan keluarga terhadap kinerja perusahaan. Kehadiran komisaris independen memberikan fungsi pengawasan dalam perusahaan sehingga pengawasan sebelumnya oleh kepemilikan keluarga semakin efektif dan memperkuat hubungan kepemilikan keluarga terhadap kinerja perusahaan.

Implikasi dari penelitian ini adalah memberikan bukti secara empiris terkait peran corporate governance dalam memoderasi struktur modal dan struktur kepemilikan terhadap kinerja perusahaan. Penelitian ini menunjukkan bahwa penggunaan utang pada struktur modal mampu memberikan pengaruh positif terhadap kinerja perusahaan, dimana utang dapat berperan sebagai sumber pembiayaan eksternal perusahaan serta memberikan manfaat sebagai perlindungan pajak. Corporate governance pada penelitian ini membuktikan mampu memoderasi pengaruh kepemilikan keluarga terhadap kinerja perusahaan. Corporate governance berperan dalam membantu mengurangi masalah keagenan serta memperkuat pengawasan perusahaan. Implikasi terapan penelitian ini bagi perusahaan adalah dapat menambah utang untuk meningkatkan kinerja perusahaan dengan memperhatikan titik optimalnya. Perusahaan juga dapat mengoptimalkan peran komisaris independen sebagai corporate governance dalam perusahaan untuk meningkatkan pengawasan dalam perusahaan sehingga kinerja perusahaan juga meningkat.

Keterbatasan pada penelitian ini adalah penelitian ini menggunakan satu proksi kinerja perusahaan yaitu Tobin's $q$. Penelitian selanjutnya dapat menggunakan proksi kinerja perusahaan lain, serta dapat menggunakan lebih dari satu proksi kinerja perusahaan yang menjelaskan kinerja perusahaan dari market base serta accounting base (Haryono et al., 2017). Penelitian mendatang 
juga dapat menambahkan jenis kepemilikan lain seperti kepemilikan pemerintah, karena kepemilikan pemerintah dapat menjadi mekanisme pengawasan dalam manajemen perusahaan untuk mendorong manajemen dalam pengungkapan informasi (Dewayanto, 2018). Selain itu penelitian mendatang juga perlu melihat ultimate beneficial owner, karena banyak perusahaan yang belum melaporkan kepemilikan dari sebuah korporasi sehingga pemerintah sulit melakukan pengawasan terhadap kepemilikan dalam sebuah korporasi (Ariani, 2020).

\section{DAFTAR PUSTAKA}

Abdallah, A. A. N., \& Ismail, A. K. (2017). Corporate Governance Practices, Ownership Structure, and Corporate Performance in The GCC Countries. Journal of International Financial Markets, Institutions and Money, 46, 98-115. https://doi.org/10.1016/j.intfin.2016.08.004

Agustin, H. E., \& Oktavianna, R. (2019). Pengaruh Porsi Kepemilikan Publik, Proporsi Dewan Komisaris Independen, dan Ukuran KAP terhadap Pengungkapan Sukarela. Jurnal Akuntansi Berkelanjutan Indonesia, 2(1), 93-103.

Ariani, N. V. (2020). Beneficial Owner: Mengenali Pemilik Manfaat dalam Tindak Pidana Korupsi. Jurnal Penelitian Hukum De Jure, 20(1), 71-84. Retrieved from https://core.ac.uk/download/pdf/288278819.pdf

Arouri, H., Hossain, M., \& Muttakin, M. B. (2014). Effects of Board and Ownership Structure on Corporate Performance. Journal of Accounting in Emerging Economies, 4(1), 117-130. https://doi.org/10.1108/jaee-02-2012-0007

Artini, L. G. S., \& Diantini, N. N. A. (2014). Struktur Kepemilikan Saham terhadap Kebijakan Utang Perusahaan di Bursa Efek Indonesia. Jurnal Keuangan dan Perbankan, 18(3), 396408. Retrieved from http://jurnal.unmer.ac.id/index.php/jkdp/article/view/818

Astuti, A. D., Rahman, A., \& Sudarno. (2015). Pengaruh Kepemilikan Keluarga terhadap Kinerja Perusahaan dengan Agency Cost sebagai Variabel Moderating. Jurnal Dinamika Akuntansi, 7(2), 98-108. https://doi.org/10.15294/jda.v7i2.4120

Astuti, F. P., Anisykurlillah, I., \& Murtini, H. (2014). Pengaruh Kinerja Lingkungan dan Kepemilikan Asing terhadap Kinerja Keuangan. Accounting Analysis Journal, 3(4), 493500. https://doi.org/10.15294/aaj.v3i4.4211

Bursa Efek Indonesia. (2020). Statistik Pasar Modal. Bursa Efek Indonesia. Jakarta: Indonesia.

Carney, M., Estrin, S., Liang, Z., \& Shapiro, D. (2019). National Institutional Systems, Foreign Ownership and Firm Performance: The Case of Understudied Countries. Journal of World Business, 54(4), 244-257. https://doi.org/10.1016/j.jwb.2018.03.003

Chu, W. (2011). Family Ownership and Firm Performance: Influence of Family Management, Family Control, and Firm Size. Asia Pacific Journal of Management, 28(4), 833-851. https://doi.org/10.1007/s10490-009-9180-1

Chung, K. H., \& Zhang, H. (2011). Corporate Governance and Institutional Ownership. Journal of Financial and Quantitative Analysis, 46(1), 247-273. https://doi.org/10.1017/S0022109010000682

Claessens, S., \& Yurtoglu, B. B. (2013). Corporate Governance in Emerging Markets: A Survey. Emerging Markets Review, 15, 1-33. https://doi.org/10.1016/j.ememar.2012.03.002

Detthamrong, U., Chancharat, N., \& Vithessonthi, C. (2017). Corporate Governance, Capital Structure and Firm Performance: Evidence From Thailand. Research in International Business and Finance, 42, 689-709. https://doi.org/10.1016/j.ribaf.2017.07.011 
Dewata, E., Jauhari, H., Sari, Y., \& Jumarni, E. (2018). Pengaruh Biaya Lingkungan, Kepemilikan Asing dan Political Cost terhadap Kinerja Perusahaan Pertambangan di Indonesia. Jurnal AKSI (Akuntansi dan Sistem Informasi), 3(2), 122-132. https://doi.org/10.32486/aksi.v2i2.271

Dewayanto, T. (2018). Pengaruh Kepemilikan Pemerintah, Ukuran KAP, dan Board Age terhadap Pengungkapan Pengendalian Internal. Jurnal Ilmiah Ekonomi, 13(2), 280-300. Retrieved from https://ejournal.stiepena.ac.id/index.php/fe/article/view/296/234

Ditta, A. S. A., \& Setiawan, D. (2019). Corporate Governance in Indonesia: One Decade Perspective. Jurnal Keuangan dan Perbankan, 23(1), 61-77. https://doi.org/10.26905/jkdp.v23i1.2182

Febrianti, K., \& Dewi, N. H. U. (2019). The Effect of Corporate Governance on Company Value. The Indonesian Accounting Review, 9(2), 155-168. https://doi.org/10.14414/tiar.v9i2.1769

Ghofar, A., \& Noviandry, F. (2018). Foreign Ownership, Corporate Governance Mechanism and Technical Efficiency of Indonesia Banking Industry. Jurnal Keuangan dan Perbankan, 22(4), 734-746. https://doi.org/10.26905/jkdp.v22i4.2461

Haryono, S. A., Fitriany, F., \& Fatima, E. (2017). Pengaruh Struktur Modal dan Struktur Kepemilikan terhadap Kinerja Perusahaan. Jurnal Akuntansi dan Keuangan Indonesia, 14(2), 119-141. https://doi.org/10.21002/jaki.2017.07

Hassan, H. (2016). Debt and Ownership Concentration as Corporate Governance Mechanisms: Evidence from The Largest Australian Firms. International Business Management, 10(17), 3921-3928. https://doi.org/10.36478/ibm.2016.3921.3928

Heder, H., \& Priyadi, M. P. P. (2017). Pengaruh Kinerja Keuangan terhadap Nilai Perusahaan dengan Good Corporate Governance sebagai Variabel Pemoderasi. Jurnal Ilmu dan Riset Akuntansi, 6(7), 1-25. Retrieved from http://jurnalmahasiswa.stiesia.ac.id/index.php/jira/article/view/1333/1354

Hermuningsih, S. (2013). Pengaruh Profitabilitas, Growth, Opportunity, Struktur Modal terhadap Nilai Perusahaan pada Perusahaan Publik di Indonesia. Buletin Ekonomi Moneter dan Perbankan, 16(2), 127-148. https://doi.org/10.21098/bemp.v16i2.27

Jensen, M. C., \& Meckling, H. (1976). Theory of The Firm: Managerial Behavior, Agency Costs and Ownership Structure. Journal of Financial Economics, 3(4), 305-360. https://doi.org/10.1016/0304-405X(76)90026-X

Kayo, E. K., \& Kimura, H. (2011). Hierarchical Determinants of Capital Structure. Journal Of Banking And Finance, 35(2), 358-371. https://doi.org/10.1016/j.jbankfin.2010.08.015

Margaritis, D., \& Psillaki, M. (2010). Capital Structure, Equity Ownership and Firm Performance. Journal of Banking and Finance, 34(3), 621-632. https://doi.org/10.1016/j.jbankfin.2009.08.023

Maury, B. (2006). Family Ownership and Firm Performance: Empirical Evidence from Western European Corporations. Journal of Corporate Finance, 12(2), 321-341. https://doi.org/10.1016/j.jcorpfin.2005.02.002

Mollah, S., Farooque, O. A, \& Karim, W. (2012). Ownership Structure, Corporate Governance and Firm Performance: Evidence from An African Emerging Market. Studies in Economics and Finance, 29(4), 301-319. https://doi.org/10.1108/10867371211266937 
Moradi, M., \& Velashani, M. A. B. (2017). Corporate Governance, Product Market Competition, and Firm Performance: Evidence from Iran. Humanomics, 33(1). https://doi.org/http://dx.doi.org/10.1108/H-10-2016-0075

Morck, R., Wolfenzon, D., \& Yeung, B. (2005). Corporate Governance, Economic Entrenchment, and Growth. Journal of Economic Literature, 43(3), 655-720. https://doi.org/10.1257/002205105774431252

Musallam, S. R. M. (2015). Relationships Between Ownership Structures and Corporate Performance: Evidence From Malaysia. Mediterranean Journal of Social Sciences, 6(3), 70-76. https://doi.org/10.5901/mjss.2015.v6n3s1p70

Myers, S. C. (1977). Determinants of Corporate Borrowing. Journal of Financial Economics, 5, 147-175. https://doi.org/10.1253/circj.CJ-16-0846

Nguyen, T., Locke, S., \& Reddy, K. (2014). A Dynamic Estimation of Governance Structures and Financial Performance for Singaporean Companies. Economic Modelling, 40, 1-11. https://doi.org/10.1016/j.econmod.2014.03.013

Noviani, A. V., Atahau, A. D. R., \& Robiyanto, R. (2019). Struktur Modal, Profitabilitas, dan Nilai Perusahaan: Efek Moderasi Good Corporate Governance. Jurnal Ekonomi dan Bisnis, 22(2), 391-415. https://doi.org/10.24914/jeb.v22i2.2601

Oluwagbemiga, O. E. (2013). Perceived Relationship Between Corporate Capital Structure and Firm Value in The Kenyan Listed Companies. Research Journal of Finance and Accounting, 4(19), 157-165. Retrieved from http://www.iiste.org/Journals/index.php/RJFA/article/viewFile/9511/9833

Pieper, T. M., Klein, S. B., \& Jaskiewicz, P. (2008). The Impact of Goal Alignment on Board Existence and Top Management Team Composition: Evidence From Family Influenced Businesses. Journal of Small Business Management, 46(3), 372-394. https://doi.org/10.1111/j.1540-627X.2008.00249.x

Purkayastha, S., Veliyath, R., \& George, R. (2019). The Roles of Family Ownership and Family Management in The Governance of Agency Conflicts. Journal of Business Research, 98, 50-64. https://doi.org/10.1016/j.jbusres.2019.01.024

Purnamawati, I. G. A., Yuniarta, G. A., \& Astria, P. R. (2017). Good Corporate Governance dan Pengaruhnya terhadap Nilai Perusahaan Melalui Corporate Social Responsibility Disclosure. Jurnal Keuangan dan Perbankan, 21(2), 276-286. https://doi.org/10.26905/jkdp.v21i2.505

Rahmawati, N. B., \& Handayani, R. S. (2017). Analisis Pengaruh Karakteristik Corporate Governance terhadap Kinerja Perusahaan. Diponegoro Journal of Accounting, 6(1), 1-12. Retrieved from https://ejournal3.undip.ac.id/index.php/accounting/article/view/18214

Roossiana, A. I., \& Bustaman, Y. (2015). Majority Shareholder: Large Shareholder, Family Ownership, Institution Ownership and Its Impact on Firm Performance. Business and Management Studies Journal, 3(1), 16-27. https://doi.org/10.33555/ijembm.v3i1.67

Sacristán-Navarro, M., Gómez-Ansón, S., \& Cabeza-García, L. (2011). Family Ownership and Control, The Presence of Other Large Shareholders, and Firm Performance: Further Evidence. Family Business Review, 24(1), 71-93. https://doi.org/10.1177/0894486510396705

Setiawan, R., Adelisa, R., \& Ratri, I. N. (2020). Corporate Governance, CEO Tenure and Capital Structure. Jurnal Manajemen dan Bisnis Indonesia, 6(2), 204-209. https://doi.org/10.31838/jcr.07.16.55 
Siagian, F. T. (2011). Ownership Structure and Governance Implementation: Evidence from Indonesia. International Journal of Business, Humanities and Technology, 1(3), 187-202. Retrieved from http://www.ijbhtnet.com/journals/Vol_1_No_3_November_2011/21.pdf

Stulz, R. M. (1990). Managerial Discretion and Optimal Financing Policies. Journal of Financial Economics, 26(1), 3-27. https://doi.org/10.1016/0304-405X(90)90011-N

Surjadi, A., Vania, I., Wijantini, \& Yuliati, R. (2018). Pengaruh Kepemilikan Institusional terhadap Struktur Modal dan Nilai Perusahaan. Studi Akuntansi dan Keuangan Indonesia, 1(2), 162-185. https://doi.org/https://doi.org/10.21632/saki.1.2.110-133

Uzliawati, L., Nofianti, N., \& Ratnasari, D. P. (2016). Struktur Modal, Investment Opportunity Set, Likuiditas dan Nilai Perusahaan. Jurnal Keuangan dan Perbankan, 20(2), 195-203. Retrieved from http://jurnal.unmer.ac.id/index.php/jkdp/article/view/254

Wairisal, R. J. A. I., \& Hariyati. (2021). Pengaruh Kualitas Laba terhadap Nilai Perusahaan dengan Variabel Moderasi Corporate Governance. Jurnal Pendidikan Akuntansi, 9(1), 71-78. Retrieved from https://ejournal.unesa.ac.id/index.php/jpak/article/view/38891

Wendy. (2020). Efek Moderasi Size dalam Pengungkapan Sukarela: Bukti Empiris di Bursa Efek Indonesia. Jurnal Ekonomi Bisnis dan Kewirausahaan, 9(1), 58-70. https://doi.org/http://dx.doi.org/10.26418/jebik.v9i1.37244

Widyawati, N., Trinugroho, I., \& Untoro, W. (2018). Family Ownership, Women in Top Management, and Risk-Taking: Evidence from Indonesia. Jurnal Keuangan dan Perbankan, 22(4), 606-613. https://doi.org/10.26905/jkdp.v22i4.2452

Wijaya, H., \& Wardani, R. P. (2017). Debt and Agency Conflict in Indonesia Manufacturing Firms. Jurnal Keuangan dan Perbankan, 21(2), 200-210. Retrieved from http://jurnal.unmer.ac.id/index.php/jkdp/article/view/659/pdf_2

Wiranata, Y. A., \& Nugrahanti, Y. W. (2013). Pengaruh Struktur Kepemilikan terhadap Profitabilitas Perusahaan Manufaktur di Indonesia. Jurnal Akuntansi dan Keuangan, 15(1), 15-26. https://doi.org/10.9744/jak.15.1.15-26

Yanti, N., Sarwani, \& Rosari, N. (2021). Karakteristik Perusahaan dan Pengungkapan Corporate Social Responsibility Dimoderasi Good Corporate Governance terhadap Nilai Perusahaan. Organum: Jurnal Saintifik Manajemen dan Akuntansi, 04(01), 55-71. Retrieved from http://ejournal.winayamukti.ac.id/index.php/Organum/article/view/129/40

Zraiq, M. A. A., \& Fadzil, F. H. B. (2018). The Impact of Ownership Structure on Firm Performance: Evidence From Jordan. International Journal of Accounting, Finance and Risk Management, 3(1), 1-4. https://doi.org/10.11648/j.ijafrm.20180301.12 